\title{
STUDY OF SELECTED BIOCHEMICAL AND PHYSIOLOGICAL CHANGES AMONG THE INFECTED BY ROOT KNOT NEMATODE AND HEALTHY PLANTS OF BITTER GOURD IN FOUR LOCALITIES AT MUZAFFARPUR
}

\author{
RUCHI $^{\mathrm{a} 1}$ AND S.N. SINGH \\ ${ }^{\mathrm{ab}}$ Department of Zoology, B.R. Ambedkar Bihar University, Muzaffarpur, Bihar, India
}

\begin{abstract}
Plants have developed certain mechanisms to protect themselves from the pathogens. This pathogen after infection destroys or disturbs the synthesis of such chemicals. Among the resistant species these are not affected but in sensitive they are influenced by this pathogen. Present study was aimed to analyse the chlorophyll contents of the leaves, the sugars of the roots \& stem, the phenylalanine ammonia lysate and peroxidase activities among the healthy and infected by root knot disease causing nematode, Meloidogyne incognita. It was noted that both chlorophyll-a and b, were influenced in the infected plants. Further maximum percentage of decrease in chlorophyll-a was found among the infected plants collected from Krishnapuri area, while maximum chlorophyll-b decreased among the plants collected from Professor Colony of the town. It was further observed that the sugar contents increased it he roots, while it decreased among the shoots. Maximum decrease $\mathbf{- 6 0 . 7 7}$ was noted among the plants collected from Krishnapuri area, while it was minimum among the plants collected form Professor Colony (-48.45). Activity of phenylalanine ammonia lyaste revealed maximum gain 48.95 among the plants collected form Nayatola area, where as it was the minimum $\mathbf{2 1 . 8 3}$ among the plants collected from Krishnapuri. Peroxidase enzyme activity was also studied. Here maximum increase $45.41 \%$ was noted among the infected plants collected form Krishnapuri, followed by $\mathbf{4 3 . 2 3} \%$ among the plants collected from Professor Colony.
\end{abstract}

KEYWORDS: Root Knot, Bitter Gourd, Meloidogyne incognita, Phenylalanine Ammonia Lysate, Peroxidase

Bitter gourd (Momordica charantia L.) of family Cucurbitaceae, is an economically important crop, being widely cultivated in different states of India as well as different other countries of the world. It is being used as vegetable as well as medicinal plant. Momordica charantia is cultivated largely due to its nutritional and medicinal properties (Satkar et al., 2013). The fruit of bitter gourd has higher content of folate and vitamin $\mathrm{C}$ and Vitamin A. It has medicinal value for the treatment of infectious diseases and specially diabetes as hypohlycemic agent (Grover and Yadav, 2004). The crop is being attacked by different pathogens like bacteria, fungi, nematodes and viruses which cause great loss to its production. Among them fusarium wilt and root knot nematode have been reported as major limiting factors affecting cultivation of bitter gourd (Lin et al., 1998). Root knot nematode, belonging to genus Meloidogyne has been reported to be predominantly associated with bitter gourd. Root knot nematodes are obligate, sedentary parasites of vascular tissues of plant roots. After entry into the host, they form root galls or knot which hamper the uptake of water and nutrients by the roots, resulting poor growth and yield. Infected plants reveal, poor root systems with fewer feeder roots (Anwar and Javid, 2010). Based on the above ground and underground system the infected plants can be recognized easily.

Root knot disease of Cucurbits, including Momordica charantia has been studied by different workers. In addition to its survey and control measures biochemical changes in the infected plants have been studied by different workers. Dasgupta et al., (1981), Tayal and Agarwal (1982), Ganguly and Dasgupta (1983), Swain \& Prasad (1988), Mohanty and Pathak (1990), Nagesh et al., (1998), Chakrabory and Mishra (2002), Devrajan and Rajendra (2002), Mohammad and Hasab (2005), Mishra and Mohanty (2007), Rani et al., (2008), Nayak and Mohanty (2010), Chaudhary et al., (2013), Gautam and Poddar (2014), Nikoo et al., (2014), Ramchandra et al., (2015), Nayak and Pandey (2016), Nayak et al., (2016), Mahapatra and Nayak (2019). Similarly, loss in yield and population density have been studied by Jan et al., (2007), Chandra et al., (2010), Khan et al., (2012), Singh et al., (2012), Anwar et al., (2013), Singh and Kumar (2013), Gautam et al., (2014) and Pungalendhi and Thiruvengadan (2016). In the present study selected biochemical changes in the infected and healthy plants of bitter gourd have been studied.

\section{MATERIALS AND METHODS}

Based on the above ground symptoms, chlorotic patches on the leaves, deformed leaves, fruits, reduced fruit setting, poor growth of the branches and underground symptoms such as galls on the roots, decaying root tips, the disease caused by root knot nematode Meloidogyne incognita was located in the field.

${ }^{1}$ Corresponding author 
The galls containing roots and rhizospheric soil were used for detection and confirmation of the disease.

Infected plants of bitter gourd were located in four different localities. Similarly, healthy plants were also located in the same field. Now samples such as leaves, roots and stems were collected from healthy as well as infected plants for the estimation of chlorophylls, Sugar, and enzyme activities among the infected as well as the healthy plants.

\section{Estimation of Chlorophyll}

Both healthy as well as leaves of infected plants were collected from different localities and brought in the laboratory in the separate polybags. These leaves were washed properly and extra water was blotted with filter paper. Now the midribs of the leaves were removed with the help of a sharp blade. $150 \mathrm{mg}$ leaf was taken separately from the healthy as well as the infected plants. These leaves were chopped and kept in a conical flask containing $50 \mathrm{ml}$, of $80 \%$ acetone. Above flasks were stored in the dark of 24 hours, for the extraction of chlorophylls. Next day the extracts were filtered through Whatman No.-1 filter paper. The filtrate was used for the estimation of chlorophyll-a and chlorophyll-b. The absorbance of the extract was taken at $645 \mathrm{~nm}$ and 663 $\mathrm{nm}$ using Spectrophotometer. $80 \%$ Acetone was used as the blank.

The amount of chlorophyll-a and chlorophyll-b was calculated by using the following formula:

\section{Chlorophyll-a (Mg/g fresh weight of leaf $)=$}

$$
12.7 X(D-663)-2.69 X(D-645) X \frac{V}{1000 X W}
$$

Chlorophyll-b $(\mathrm{Mg} / \mathrm{g}$ fresh weight of leaf $)=$

$$
22.9 X(D-645)-4.68 X(D-663) X \frac{V}{1000 X W}
$$

Total Chlorophyll (Mg/g fresh weight of leaf) $=$

$$
20.2 X(D-645)+8.02 X(D-663) X \frac{V}{1000 X W}
$$

Where,

$$
\begin{aligned}
& \text { D-645 = Optical density at } 645 \mathrm{~nm} \\
& \text { D-663 = Optical density at } 663 \mathrm{~nm} \\
& \mathrm{~V}=\text { Final volume of } 80 \% \text { Acetone chlorophyll }
\end{aligned}
$$
extract in $\mathrm{ml}$.

$\mathrm{W}=$ Fresh weight in $\mathrm{g}$ of different leaves, taken form healthy ad infected plants.

\section{Estimation of Sugar Contents in Roots \& Shoots of Infected and Healthy Plants of Bitter Gourd}

Roots and shoots of healthy as well as infected plants were collected from different localities. They were brought in the laboratory and washed properly with tap water, followed by distilled water. Fresh root as prepared above was chopped into pieces and was dried at room temperature. Above dried roots and shots were grounds to powder separately. $100 \mathrm{mg}$ of powder of ground roots were taken in $15 \mathrm{ml}$ centrifuge tube containing $10 \mathrm{ml}$ of $80 \%$ ethanol. The mouth of the centrifuge tube was covered with polythene paper and it was kept in water bath at $80-85^{\circ} \mathrm{C}$ for 30 minutes. The tubes were allowed to cool and were centrifuged for 15 minutes at $2000 \mathrm{rpm}$. The supernatant was carefully taken in a $25 \mathrm{ml}$ volumetric flask with the help of pipette. Above method was repeated and supernatant was collected in $25 \mathrm{ml}$ volumetric flask. The volume was made $25 \mathrm{ml}$ by adding sterilized distilled water. It was filtered through Whatman No.-1filter paper. The extract taken from healthy as well as infected roots and shoots were stored and labeled for the same and the localities and were used for the estimation of sugar.

\section{Estimation of Sugar}

$2 \mathrm{ml}$ of the above extract was taken in $50 \mathrm{ml}$ volumetric flask and volume was made $50 \mathrm{ml}$ by adding distilled water. $5 \mathrm{ml}$ of this was taken in $25 \mathrm{ml}$ volumetric flask. In the mean time standard of $0 \mathrm{ml}, 1 \mathrm{ml}, 1.5 \mathrm{ml}$ and 2 $\mathrm{ml}$ of $100 \mathrm{mg} / \mathrm{l}$ glucose solution were taken in $25 \mathrm{ml}$ volumetric flasks. The volume of these standards solution was made up to $5 \mathrm{ml}$ by adding distilled water and 2 drops of 80 percent ethanol. Above flask containing samples and standard were placed on ice-bath. To each volumetric flask $10 \mathrm{ml}$ of anthrone ( $2 \mathrm{~g}$ anthrone in one liter of $95 \% \mathrm{H}_{2} \mathrm{So}_{4}$ ) was added. The flasks were shaken slowly and then thoroughly. Above flask were kept in boiling water bath for exactly 7.5 minutes. Flasks were allowed to cool on ice-bath. The absorbance was taken at $630 \mathrm{~nm}$. The sugar content was calculated with the help of standard curve.

\section{Estimation of Enzyme Activity}

\section{Phenylalanine Ammonia Lysate (PAL)}

Above powdered roots prepared from the roots of infected as well as healthy roots were used for the above experiments.1g of powered was homogenized in prechilled $10 \mathrm{ml}$ acetone at $15^{\circ} \mathrm{C}$. The homogenate was filtered through Whatman filter paper No.-1. It was again rinsed with $10 \mathrm{ml}$ of acetone and filtered. The filtrate was 
dried at room temperature and stored in freeze. Above residue was suspended in $0.1 \mathrm{~m}$ cold borate buffer $(\mathrm{pH}$ 8.8). Here $6 \mathrm{ml}$ buffer was used for $1 \mathrm{~g}$ of sample. The suspension was incubated at $0^{0} \mathrm{C}$ for 1 hour. It was filtered through cheese cloth. The filtrate was centrifuged at $5000 \mathrm{rpm}$ at $4^{0} \mathrm{c}$ for 10 minutes. The aliquot was sued as the source of enzyme.

$1.5 \mathrm{ml}$ of above extract was taken in a tube and 1 $\mathrm{ml}$ of $0.05 \mathrm{M}$, L-phenylalanine and $2.5 \mathrm{ml}$ of $0.1 \mathrm{M}$ borate buffer was added to it. It was incubated for 1 hour at $40^{\circ} \mathrm{C}$ and the reaction was stopped after it by adding $0.1 \mathrm{ml}$ of $5 \mathrm{~N} \mathrm{Cl}$ and $7.5 \mathrm{ml}$ ether. The mixture was evaporated to complete dryness and residue was dissolved in $0.05 \mathrm{~N}$, $\mathrm{NaoH}$. The amount of trans cinnamic acid formed above was estimated by measuring the absorbance at $290 \mathrm{~nm}$. Blank was used without the extract. The enzyme activity was expressed as $\mathrm{mg}$ of trans-cinnamic acid formed per gram of fresh weight of roots of healthy as well as infected plants of bitter gourd.

\section{Estimation of Peroxidase Activity in Roots}

Well cleaned roots were taken. Now $1 \mathrm{~g}$ of root was grinded with $5 \mathrm{ml}$ of cold $1 \mathrm{M}$ phosphate buffer $(\mathrm{pH}$ 7.0) in a pre chilled mortar and pestle. The homogenate was centrifuged at $15000 \mathrm{rpm}$ at $4^{0} \mathrm{C}$ for 30 minutes the supernatant was used as the source of the enzyme.

$1 \mathrm{ml}$ of above extract was mixed with $2 \mathrm{ml}$ of $0.1 \mathrm{M}$ phosphate buffer $(\mathrm{pH} 7.0) 1 \mathrm{ml}$ of $0.01 \mathrm{M}$ pyrogallol, $1 \mathrm{ml}$ of $0.005 \mathrm{M} \mathrm{H}_{2} \mathrm{O}_{2}$. It was left for 5 minutes at $25^{\circ} \mathrm{C}$ and the reaction was stopped by adding 1 $\mathrm{ml}$ of $1.5 \mathrm{~N} \mathrm{H}_{2} \mathrm{So}_{4}$. The absorption was measured at 420 $\mathrm{nm}$ to measure the amount of purpurogallin formed above. The enzyme activity was expressed in optical density absorbency units.

All the experiments were repeated thrice and the mean of the data was taken for discussion. The data were placed in table 1-4 respectively.

Table 1: Reduction in chlorophyll content (a, b, total) due to infection by Meloidogyne incognita the root knot casing plant parasitic nematode

\begin{tabular}{|c|c|c|c|c|c|c|c|c|c|c|c|c|}
\hline \multirow[b]{2}{*}{ Site } & \multicolumn{4}{|c|}{ Chlo-a mg/g leaf } & \multicolumn{4}{|c|}{ Chlo-b mg/g leaf } & \multicolumn{4}{|c|}{ Total Chlo- mg/g leaf } \\
\hline & Healthy & Infected & Mean & $\begin{array}{c}\% \\
\text { loss }\end{array}$ & Healthy & Infected & Mean & $\begin{array}{c}\% \\
\text { loss }\end{array}$ & Healthy & Infected & Mean & $\begin{array}{c}\% \\
\text { loss }\end{array}$ \\
\hline $\mathrm{A}$ & 2.978 & 1.982 & 2.48 & 33.45 & 1.484 & 1.326 & 1.41 & 30.65 & 4.462 & 3.308 & 3.885 & 25.86 \\
\hline B & 2.754 & 1.864 & 2.310 & 32.33 & 1.280 & 0.946 & 1.113 & 26.09 & 4.034 & 2.81 & 3.422 & 30.03 \\
\hline $\mathrm{C}$ & 2.886 & 2.028 & 2.460 & 29.73 & 1.390 & 0.622 & 1.06 & 44.75 & 4.276 & 2.65 & 3.463 & 44.33 \\
\hline $\mathrm{D}$ & 2.678 & 1.926 & 2.302 & 28.08 & 1.242 & 0.646 & 0.944 & 47.98 & 3.920 & 1.972 & 2.945 & 49.69 \\
\hline
\end{tabular}

$\mathrm{A}=$ Krishnapuri, $\mathrm{B}=$ Damuchak, $\mathrm{C}=$ Naya Tola, $\mathrm{D}=$ Professor Colony

Table 2: Percentage increase/decrease of total sugar content in the root and shot of bitter gourd infected by Meloidogyne incognita

\begin{tabular}{|c|c|c|c|c|c|c|c|c|}
\hline \multirow{2}{*}{ Site } & \multicolumn{2}{|c|}{ Healthy } & \multicolumn{2}{c|}{ Infected } & \multicolumn{2}{c|}{ Mean } & \multicolumn{2}{c|}{ \% increase/decrease over control } \\
\cline { 2 - 9 } & Root & Shoot & Root & Shoot & Root & Shoot & Root & Shoot \\
\hline A & 1.674 & 11.562 & 2.784 & 4.536 & 2.117 & 8.049 & 66.30 & -60.77 \\
\hline B & 1.878 & 13.456 & 2.842 & 6.528 & 2.360 & 9.992 & 51.33 & -51.49 \\
\hline C & 1.756 & 14.562 & 3.788 & 7.382 & 2.772 & 10.972 & 115.72 & -49.93 \\
\hline D & 1.712 & 14.884 & 3.826 & 7.658 & 2.769 & 11.271 & 123.48 & -48.45 \\
\hline
\end{tabular}

$\mathrm{A}=$ Krishnapuri, $\mathrm{B}=$ Damuchak, $\mathrm{C}=$ Naya Tola, $\mathrm{D}=$ Professor Colony

Table 3: Estimation of phenylalanine ammonia lysate in infected roots by Meloidogyne incognita and in the healthy roots of bitter gourd

\begin{tabular}{|c|c|c|c|c|}
\hline \multirow{2}{*}{ Site } & \multicolumn{4}{|c|}{ Activity of phenylalanine ammonia lysate in healthy and infected root of bitter gourd mg/g } \\
\cline { 2 - 5 } & Healthy & Infected & Mean & \% increase over control (Healthy) \\
\hline A & 23.68 & 28.85 & 26.265 & +21.83 \\
\hline B & 28.26 & 39.74 & 34 & +40.62 \\
\hline C & 32.48 & 48.38 & 40.43 & +48.95 \\
\hline D & 27.54 & 38.44 & 32.99 & +39.58 \\
\hline
\end{tabular}

$\mathrm{A}=$ Krishnapuri, $\mathrm{B}=$ Damuchak, $\mathrm{C}=$ Naya Tola, $\mathrm{D}=$ Professor Colony 
RUCHI AND SINGH: STUDY OF SELECTED BIOCHEMICAL AND PHYSIOLOGICAL CHANGES AMONG...

Table 4: Percentage increase/decrease in the enzyme peroxidase in healthy and infected plants of bitter gourd by root knot nematode (Meloidogyne incognita)

\begin{tabular}{|c|c|c|c|}
\hline \multirow{2}{*}{ Site } & Enzyme activity OD units/g fresh weight of roots & \multirow{2}{*}{$\begin{array}{c}\text { increase (+) or } \\
\text { decrease (-) }\end{array}$} \\
\cline { 2 - 3 } & Healthy & Infected & +45.41 \\
\hline A & 1.284 & 1.867 & +39.82 \\
\hline B & 1.386 & 1.938 & +37.97 \\
\hline C & 1.722 & 2.376 & +43.23 \\
\hline D & 1.316 & 1.885 & \\
\hline
\end{tabular}

$\mathrm{A}=$ Krishnapuri, $\mathrm{B}=$ Damuchak, $\mathrm{C}=$ Naya Tola, $\mathrm{D}=$ Professor Colony

\section{RESULTS AND DISCUSSION}

Chlorophyll content of healthy as well as leaves of plant infected by root knot disease causing nematode was analyzed. In the present experiment, it was noted that chlo-a was reduced to $1.982 \mathrm{mg} / \mathrm{g}$ of leaves in the infected plant which were collected form Krishnapur. Similarly, Chlo-b was reduced from $1.484 \mathrm{mg} / \mathrm{g}$ to 1.326 $\mathrm{mg} / \mathrm{g}$ in infected leaves. Leaves of plants collected form Damuchak revealed that chlo-a was reduced to 1.864 $\mathrm{mg} / \mathrm{g}$ in the infected plants from $2.754 \mathrm{mg} / \mathrm{g}$ found in healthy leaves. Similarly chlo-b was reduced from 1.280 $\mathrm{mg} / \mathrm{g}$ to $0.946 \mathrm{mg} / \mathrm{g}$. Chlo-a was reduced to $0.028 \mathrm{mg} / \mathrm{g}$ in the infected leaves collected from Nayatola from 2.886 $\mathrm{mg} / \mathrm{g}$ of the healthy leaves. Here chlo-b was reduced to $0.622 \mathrm{mg} / \mathrm{g}$ in infected leaves from $1.390 \mathrm{mg} / \mathrm{g}$ of healthy leaves. Chlo-a was reduced to $1.926 \mathrm{mg} / \mathrm{g}$ in infected leaves from $2.678 \mathrm{mg} / \mathrm{g}$ of healthy leaves collected from Professor Colony at Muzaffarpur. The percentage of reduction due to infection by root knot nematode in Chloa varied from 28.08 to 33.45 . Here lower percentage for reduction was noted among the plants collected form Professor Colony where as the highest one in case of plants collected from Krishnapuri locality. Likewise, percentage of reduction in chlo-b from 26.09 to 47.98 . Here the lowest reduction was found among leaves collected from Damuchak while the highest among the plants collected form Professor Colony. Total chlorophyll also revealed decreased concentration among the infected leaves than that of the healthy one. It varied from 25.86 percent to $49.69 \%$. Here again the higher percentage of reduction was among the infected leaves collected form Professor colony than that of the others.

Chlorophyll contents are the most important constituent of the plants because, growth and yield depend on it. Once a plant is infected, its chlorophyll becomes the target and either it is degraded or no synthesis of new chlorophylls takes place. This was also evident in case of a plant infected by Meloidogyne incognita the root knot causing nematode. Present findings corroborate with the findings of Nayak et al., (2016) and Mahapatra and Nayak (2019).

In the present work percentage increase and decrease of total sugar in roots and shoots of healthy as well as infected plants were studied the mean of the data obtained was presented in table 2. From the table it may be noted that while in the roots there was gain of the sugar, in the shoot it was reduced. Maximum percentage of gain was 123.48 which were the highest and the sample was collected form Professor Colony locality. The minimum increase $51.33 \%$ was among the sample collected form Damuchak locality. Similarly, highest percentage in decrease sugar in the stem was (-60.77) in the sample collected form Krishnapuri area, followed by $(-51.49)$ in the sample collected form Nayatola.

The activity of phenylalanine ammonia lysate (PAL) was also studied in healthy as well as the infected plants. Mean of the data was presented in the table 3. PAL was measured as mg of trans-cinnamic acid formed per gram of fresh root extract. From the table it may be noted that this was $23.68 \mathrm{mg} / \mathrm{g}, 28.26 \mathrm{mg} / \mathrm{g}, 32.48 \mathrm{mg} / \mathrm{g}$ and $27.54 \mathrm{mg} / \mathrm{g}$ in the healthy roots collected form Krishnapuri, Damuchak, Nayatola nd Professor Colony localities respectively. Whereas among the infected roots collected from the same localities it was $28.85 \mathrm{mg} / \mathrm{g}$, $39.74 \mathrm{mg} / \mathrm{g}, 48.38 \mathrm{mg} / \mathrm{g}$ and $38.44 \mathrm{mg} / \mathrm{g}$ respectively. The percentage of increase over the healthy one was therefore, $28.83,40.62,48.95$ and 39.58 respectively.

Percentage increase and decrease in the enzyme peroxidase in healthy and infected plants of bitter gourd were also studied the mean of the data was presented $n$ table 4. Here highest increased percentage in peroxidase (45.41) was found in the infected plant sample collected form Krishnapuri locality, which was followed in the sample 43.23 collected form Professor colony. It was recorded 39.82 among the sample collected form Damuchak locality. The sample collected form Nayatola locality revealed $37.97 \%$ increase only. 
Physiological and biochemical in different plants infected by the root knot causing nematode Meloidogyne incognita have been reported by Ganguly and Dasgupta (1983) in brinjal, Chakrabory and Mishra (2002) in chick pea, Mohammad \& Hasab (2005) in cotton, Mishra and Mohanty (2007), Rani et al., (2008), Chakraborty et la., (2013) in tomato. Nikoo et la., (2014) in tomato, and Mahapatra et al., (2019) in bitter gourd. Their findings are in agreement with the present observations as they considered the aforesaid parameters among the above crops and reported alteration in chlorophyll contents, sugar contents, phenolics and in enzyme activates. Plants have developed biochemical defense and whenever they are attacked, these chemicals are altered due to host parasite interactions. Variations in data for same parameter in the infected plants at different locality may be due to nematode population load and soil conditions.

\section{ACKNOWLEDGEMENT}

The authors are thankful to the professor and Head, Department of Zoology, B. R. Ambedkar Bihar University, for providing Library and Laboratory facilities to carry out the work.

\section{REFERENCES}

Anwar S.A., Mahdi M.M. McKeny M.V. and Qadir A., 2013. Survey of plant parasitic nematodes associated with four vegetable crops cultivated within tunnels. Pak. J. Zoo., 45(3): 595-603.

Chakraborty V. and Mishra S.D., 2002. Evaluation of biochemical parameters for screaming resistance of chick-pea cultivars against Meloidogyne incognita. Ind. J. Nematol., 32(1): 26-29.

Chandra P., Sao R., Gautam S.K. and Poddar A.N., 2010. Initial population density and its impact on the pathogenic potential and population growth of root knot nematode Meloidogyne incognita in four species of Cucurbits. Asian J. Plant Pathol., 4: $1-15$.

Chaudhary K., Chawla N., Kaur S. and Zindal S., 2013. Analysis of biochemical parameters in tomato fruits before and after inoculation with root knot nematode (Meloidogyne incognita). Veg. Sci., 40: $178-218$.

Dasgupta D.R., Faroozi T.N.A., Ganguly A.K., Mote U.N., Ganguly S. and Prema Chandra D., 1981. On the biochemical mechanism of resistance in tomato against the root knot nematode
Meloidogyne incognita. Ind. J. of Nematol., 11: 108-115.

Devaranjan K. and Rajendra G., 2002. Biochemical alternations in resistant and susceptible banana clones due to the burrowing nematode. Ind. J. Nematol., 32(2): 159-161.

Ganguly A.K. and Dasgupta D.R., 1983. Chemical changes in brinjal plants induced by root knot nematode, Meloidogyne incognita. Ind. J. Entomol., 45(1): 45-47.

Gautam S.K. and Poddar A.N., 2014. Study on protein and sugar content in Meloidogyne incognita infested roots of bitter gourd. Int. J. of Curr. Microbiol. and Appl. Sci., 3(5): 470-478.

Gautam S.K., Sahu G., Verma B.K. and Poddar A.N., 2014. Status of root knot nematode (Meloidogyne sp.) of central plain region of Chhattishgarh State, India. Afr. J. of Micrbiol. Res., 8(16): 1663-1671.

Grover J.K. and Yadav S.P., 2004. Pharmacological actions and potential uses of Momordica charantia: A review. J. Ethnopharmacol., 93: 123-132.

Jain R.K., Mathur K.N. and Singh R.V., 2007. Estimation of losses due to plant parasitic nematodes on different crops in India. Ind. J. Nematol., 37: 219-221.

Kaur S. and Pathak M., 2011. Sources of resistance in Momordica balsamina L. to root knot nematode. Plant Disease Research, 26(2): 174-180.

Khan M.R., Mohiddin F.A., Ejaz M.N. and Khan M.M., 2012. Management of root knot disease in egg plant through application of biocontrol fungi and dry neem leaves. Tuk. J. Biol., 36: 161-169.

Lin Y.S., Hwang C.H. and Soong S.C., 1998. Resistance of bitter gourd- Luffa grafts to Fusarium oxysporum f. sp. Momordicae and their yield. Plant Protection Bulletin, 40: 121-132.

Mahapatra M. and Nayak D.K., 2019. Biochemical and physicochemical changes in susceptible and resistant bitter gourd cultivars as influenced by root knot nematode Meloidogyne incognita. J. of Entom. and Zool. Stud., 7(3): 80-87.

Mishra C.D. and Mohanty K.C., 2007. Role of phenolics and enzymes in imparting resistance to rice 
RUCHI AND SINGH: STUDY OF SELECTED BIOCHEMICAL AND PHYSIOLOGICAL CHANGES AMONG...

plants against root knot nematode Meloidogyne graminicola. Ind. J. Nematol., 37: 131-134.

Mohammad M.A. and Hasab O.SA., 2005. Biochemical alterations induced by Meloidogyne incognita infection in cotton. Int. J. Nematol., 15: 145-154.

Mohanta S. and Mohanty K.C., 2012. Biochemical and physiological alternation in Okara infected with root knot nematode, Meloidogyne incognita. J. P1. Protec. Environ., 9: 54-56.

Mohanty K.C. and Pradhan A.K., 1990. Qualitative determination of free amino acids and amides in resistant and susceptible green gram varieties inoculated with root knot nematode, Meloidogyne incognita. Comparative Physiology and Ecology, 15(1): 9-12.

Nagesh M., Dasgupta D.R. and Sirohi A., 1998. Relationship between Indole Acetic Acid oxidase, polyphenol oxides, indole acetic acid and response of tomato to Meloidogyne incognita infection. Pest Management in Hort. Ecosystem, 4: 111-115.

Nayak D.K., 2015. Effect of nematode infection on content of phenolic substances as influenced by root knot nematode Meloidogyne incognita in susceptible and resistant brinjal cultivars. Agricult. Sci. Digest, 35(2): 163-164.

Nayak D.K. and Mohanty K.C., 2010. Biochemical changes in Brinjal induced by root knot nematode Meloidogyne incognita. Ind. J. Nematol., 40(1): 43-47.

Nayak D.K. and Pandey R.K., 2016. Physiological and biochemical changes of susceptible and resistant brinjal cultivars induced by root knot nematode, Meloidogyne incognita. Journ. of Glob. Biosci., 5(7): 4358-4368.

Nikoo F.S., Sabani N., Amminian H., Mukhtarjejadi L. and Ghaderi R., 2014. Induction of systematic resistance and defense related enzymes in tomato plants using Pseudomonas fluorescence CHAO and salicylic acid against root knot nematode Meloidogyne incognita. J. Plant Prot. Res., 54:4-10.
Pugalendhi L. and Thiruvengadam R., 2016. Exploiting cucurbitaceous species as rot stocks for Fusarium wilt in bitter gourd. Australian J. of Crop. Sci., 10(10): 1460-1465.

Ranchana P., Kanan P. and Jawaharlal M., 2015. Analysis on biochemical basis of root knot nematode (Meloidogyne incognita) resistance in Polianthes tuberosa. The Bioscan, 9:943-947.

Rani I.C., Veeraragavathatham and Sanjutha S., 2008. Analysis on biochemical basis of root knot nematode, Meloidogyne incognita resistance in tomato (Lycopersicon esculentum). Res. J. Agric. Biol. Sci., 4: 866-870.

Reddy D.D.R., 1985. Analysis of crop losses in tomato due to Meloidogyne incognita. Indian $\mathrm{J}$. Nematol., 15: 55-59.

Sahu G., Gautam S.K. and Poddar A.N., 2015. Suitable hosts of root knot nematode attack an assessment on the basis of morphological size variations and population density under field conditions. Int. J. Phytopathol., 4:87-92.

Satkar K.P., Kulthe A.A. and Challee P.R., 2013. Preparation of bitter gourd ready to serve beverage and effect of storage temperature on keeping quality. The Bioscan, 8: 115-117.

Singh R. and Kumar U., 2013. Assessment of nematode distribution and yield loss in vegetable crops of Uttar Pradesh, India. Int. J. of Sci. and Res., 4(5): 2812-2816.

Singh S.K., Conde B. and Hodda M., 2012. Root knot nematode (Meloidogyne incognita) on Bittermelon (Momordica charantia) near Darwin, Australia. Aust. Plant Dis., 7(2): 75-78.

Swain B.N. and Prasad J.S., 1988. Chlorophyll content in rice as influenced by the root knot nematode, $M$. graminicola infection. Current Science, 57(16): 895-896

Tayal M.S. and Agarwal M.L., 1982. Biochemical alteration in galls induced by Meloidogyne incognita some hydrolyzing enzymes and related chemical metabolites. Ind. J. Nematol., 12: 379382. 